Applied Research on Civil Engineering and Environment (ARCEE) VOL. 01 No. 01, August 2019

\title{
INVESTIGATION OF AIR CIRCULATION FOR INDOOR AIR QUALITY OF MIDDLE-CLASS APARTMENT IN JAKARTA, INDONESIA
}

\author{
Dyah Nurwidyaningrum$^{1}$, Miftahul Ulum ${ }^{2}$, Billy Septanto Syamsumarno ${ }^{3}$ \\ 1,2,3 Civil Engineering, Politeknik Negeri Jakarta, Depok, 16425, Indonesia \\ e-mail :dyah.nurwidyaningrum@sipil.pnj.ac.id ${ }^{1}$; miftahhululum296@gmail.com² \\ billyseptanto14@gmail.com ${ }^{3}$
}

\begin{abstract}
The most significant energy used in middle-class apartments is the air circulation unit. The use of energy from the air circulation system is related to the comfort of the user in the housing unit, so it adjusts to the applicable standard. The objection of this study is to investigate the optimization of the air circulation system in middle-class apartments in an urban area. The method is a comparative study of the government standard. The stages of the research did site observation, take air quality measurement, and interview with the questionnaire. Indoor air quality data collected are temperature, relative humidity, $\mathrm{CO}$, and $\mathrm{CO}_{2}$. The data measurement compared to SNI 03-6572-2001 on Procedures for Designing Air Conditioning and Ventilation Systems in Buildings, Indonesian National Standardization. The questionnaire was to find out the comfort of residents on indoor air quality (IAQ). This study reveals that almost all air quality aspects are consistent to standard, except the temperature. The results of this study that meet the criteria related to air circulation are air movement $40 \%$, relative humidity $65.5 \%$, air movement $40 \%$, $\mathrm{CO} 78 \%$, and $\mathrm{CO}_{2} 95 \%$. The result of the questionnaires states that $72.4 \%$ of residents feel comfortable with the air quality in the dwelling unit. The size of the room and the adequacy of ventilation in the place influences the value of the air circulation system besides air movement.
\end{abstract}

Keywords: Air Circulation System; Indoor Air Quality Thermal Comfort; Dwelling Unit; Middle-Class Apartment

\section{INTRODUCTION}

Jakarta city has more middle-class apartments than the other city in Indonesia. These apartments tend to use air-conditioning for the dwelling units. The reason for the developer uses this system is the high of a temperature and relative humidity, and the unstable air quality on the city. The residents need a healthy dwelling and affordable cost of AC (Wells et al., 2015). Therefore, this study considered for investigating the factors that influence.

Previous studies have shown that drop of volatile organic compound (VOC) depends on the air circulation of the room (Harb et al., 2016). VOC is a particulate cause of indoor air quality
(IAQ). His study found that a unit of the low-cost apartment without partition has healthier than a middle-class apartment with two bedrooms in Surabaya, Indonesia (Alfata et al., 2015). It means there is a circulation problem for indoor air quality in a middle-class apartment.

$\mathrm{AC}$ is managed to set air temperature between $16-30 \mathrm{oC}$ and relative humidity between 40-60\%, the different perception between the comfort and the health concept become trouble for residents' health (Wolkoff, 2018). So, it is needed more studies on kind of IAQ affects human health. It stated that air quality and thermal satisfaction is the higher aspect of the overall environmental satisfaction (OES) (Xue 
et al., 2016). Air quality is an essential need for the residents.

SNI 03-6572-2001 is a design guideline for determining airspeed limits, temperature and humidity settings, and comfort requirements for building users (Indonesian Standardization Institute, 2001). The standard states the definition of ventilation is the process of flowing fresh air into a building in the amount needed. Regular ventilation needs equipping with air circulation devices.

In this study was emphasized on the influence of the air circulation system on the comfort of residents. With the IAQ approach, the effectiveness of air circulation will be found, which also affects the health of apartment residents. He states in the reviews on indoor air pollution (IAP) that indoor environment itself participates in the generation of potentially particle exposure (Tham, 2016). The result of this study finds the alternative design in a decision to use mechanic air circulation for a unit apartment in an urban area like Jakarta. The novelty of this study is a comparative solution on healthier and comfort of human dwelling in a high-rise building.

\section{METHODS}

This study was taken place in an apartment on the side of Jl. General Ahmad Yani Kav. 49, Cempaka Putih, Central Jakarta, the location of the golden triangle in the middle of East Jakarta, North Jakarta and Central Jakarta stands with an area of 12.9 hectares and has $80 \%$ green open space. The data was from 2 towers; furthermore, the mass of towers are Ushaped buildings. Each floor consists of 44 units and a total of 25 levels plus two basements so that one tower consists of 1100 residential units. The area per floor is approximately $1500 \mathrm{~m}^{2}$ if 1 group consists of 3 people then 132 people inhabit one floor. So, the density per floor is $11.3 \mathrm{~m}^{2} /$ person. This amount has met the minimum standard of housing in Indonesia $9 \mathrm{~m}^{2} /$ person for the lowest standard (Goverment of Republik Indonesia, 2011).

This study was conducted to determine the results of the analysis of the air circulation system. The analysis method used comparative between data measurement in units apartment with SNI 03-6572-2001. Based on this, the data of air circulation can be clarified, concrete, observable, and measurable. The data collecting is by observation, interviews, and measurements in the field. To measure air quality in the room uses the Air Quality Meter (IAQ) type Lutron AQ-9901 SD.

This Lutron AQ-9901 SDQ type is used to measure the $\mathrm{CO}, \mathrm{CO}_{2}, \mathrm{RH}$, and temperature values in the room unit. Tool placed in a table near where contains a lot of $\mathrm{CO}$ and $\mathrm{CO}_{2}$ in the room precisely in the unit pantry. Because of the pantry, there are cooking activities that can increase $\mathrm{CO}$ and $\mathrm{CO}_{2}$ levels in the air. The anemometer is used to measure the speed of AC, and this quality type recorded. AC type classified into two types. First, air conditioners from reliable brands and secondly, air conditioners are known to be quite economical.

Sampling for residents and units conducted purposive sampling. IAQ measurements were carried out on 58 randomly located units on different floors of the building. Sampling taken from three positions, namely in the living room, dining table, and kitchen, but if space is too narrow, only 2 points made.

In this study, the questionnaires headed for residents of apartment units on the 
comfort aspects of apartment units related to the circulation system. The issues are smoking habit, room cleanliness, pleasure, and disturbance. Smoking was a habit of behavior, which reduces IAQ (Gautami \& Syahruddin, 2017).

The age of respondents is generally young with a range of 18-37 years and a small number of others with an age range of 38-58 years. Most respondents are couples or young families and productive age to work and are very busy. Most of the respondents have lived in dwellings for 1-3 years, and some others have lived 4-5 years (17\%). Residents are generally young couples and young families who have children ranging from toddlers and elementary school children - a small number of elderly couples and families with teenagers. The density in units is between 2-5 people per group.

\section{RESULTS AND DISCUSSION}

\section{Relative Humidity}

The air humidity of the unit was $65.5 \%$, which met the requirements. Moisture met this criterion by temperature and solar radiation that influence the room. For air humidity, most dwellings $(68 \%$ of the units) exceed of the quality humidity were $>60 \%$. This situation is alarmed to trigger the growth of mites and fungi, then cause allergies like Rhinitis and Asthma, According to American Society of Heating, Refrigerating, and Air-Conditioning Engineers/ASHRAE (Nicklas, 2016) as shown in Figure 1. The exceeding humidity does not cause physically disturbing the residents, but the room felt stuffy and smells unpleasant, especially in the unit, which is not maintained correctly.

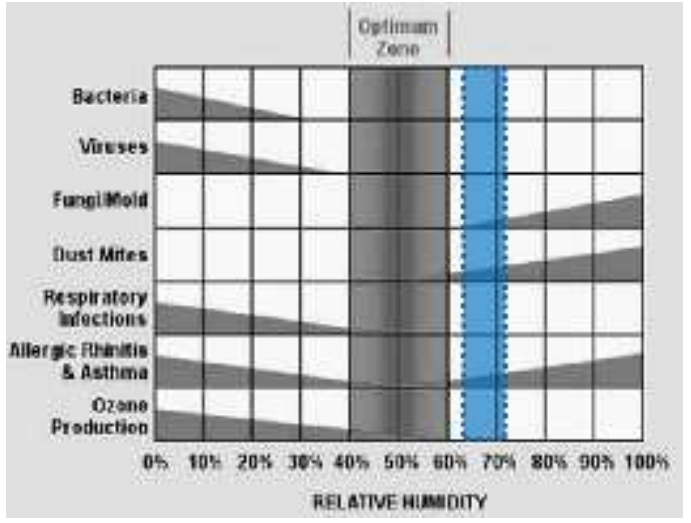

Figure 1. Occupancy humidity range on the Optimal Humidity diagram for Humans

Comfort and Health (ASHRAE, 2016)

\section{Temperature}

The temperature in the room does not meet the criteria. Then, the residents use light cloth and do slight activities. Residents (98\%) generally feel the room temperature is acceptable. The lowest temperature is $25^{\circ} \mathrm{C}$, and the highest temperature is $34^{\circ} \mathrm{C}$, with the most upper range between $29^{\circ} \mathrm{C}$ to $32^{\circ} \mathrm{C}$. The required quality standard was $18-30^{\circ} \mathrm{C}$ in SNI, but a comfortable temperature was around $24^{\circ} \mathrm{C}$. The temperature conditions in most residential units $(74 \%$ of the units) are higher than $30^{\circ} \mathrm{C}$, which are $31-34^{\circ} \mathrm{C}$. It shows the occupants are still tolerant of excessive temperatures and of course electricity needs are less for air conditioning. It supported by free occupants wearing thin clothing in the unit, unlike working in an office that has to wear formal attire. This temperature condition is above room temperature $\left(25^{\circ} \mathrm{C}\right)$. It has the potential to evaporate material containing VOC, then VOCfree material should be selected.

\section{3. $\mathrm{CO}$ and $\mathrm{CO}_{2}$}

From the measurement obtained $\mathrm{CO}$ values between 0-29 ppm and $\mathrm{CO}_{2}$ values between 331-1111 ppm. Because of SNI 03-6572-2001 does not have comparative data values of $\mathrm{CO}$ and $\mathrm{CO}_{2}$, so the comparison uses the Regulation of the Minister of Health of the Republic of 
Indonesia Number 1077 (Ministry of Health of the Republic of Indonesia, 2011). CO was 9 ppm, as much as $78 \%$ increase in $\mathrm{CO}$ value indoors caused by indoor smoking. While the $\mathrm{CO}_{2} 1000$ $\mathrm{ppm}$ is $95 \%$, the amount of $\mathrm{CO}_{2}$ produced by routine cooking activities carried out by residents every day.

The criteria for comfort are $40 \%$, the requirements are quite comfortable $43 \%$. Factors related to air quality, $\mathrm{CO}$ and $\mathrm{CO}_{2}$ ranged from 331-1111 ppm, with $\mathrm{CO} \leq 9 \mathrm{ppm}$ as much as $78 \%$ and $\mathrm{CO}_{2} \leq$ $1000 \mathrm{ppm}$ as much as 95\%. From the supporting data, it shows the condition was a good room.

\section{Air Movement}

For the air movement, the comfortable criteria which consider to SNI 03 65722001 are $0.1-0.25 \mathrm{~m} / \mathrm{s}$. The results from 58 samples are between $0.1-2.2 \mathrm{~m} / \mathrm{s}$ with $40 \%$ meet the requirements of comfort, $43 \%$ quite comfortable. The better brand of AC shows better performance and influence IAQ.

Table 1. The Influence of Air Movement

\begin{tabular}{ccccc}
\hline $\begin{array}{c}\text { Air } \\
\text { Movement } \\
(\mathbf{m} / \mathbf{s})\end{array}$ & $\begin{array}{c}\text { Temperature } \\
\left({ }^{\circ} \mathbf{C}\right)\end{array}$ & $\begin{array}{c}\text { Humidity } \\
(\%)\end{array}$ & $\begin{array}{c}\mathbf{C O} \\
(\mathbf{p p m})\end{array}$ & $\begin{array}{c}\mathbf{C O}_{2} \\
(\mathbf{p p m})\end{array}$ \\
\hline $\mathbf{0 - 0 , 1 9}$ & $32-34$ & $64-74$ & $8-29$ & $470-$ \\
& & & & 1050 \\
$\mathbf{0 , 2 - 0 , 3 9}$ & $31-33$ & $57-67$ & $0-10$ & $250-$ \\
& & & & 1000 \\
$\mathbf{0 , 4 - 0 , 7 9}$ & $30-32$ & $54-64$ & $0-7$ & $220-$ \\
& & & & 974 \\
$\mathbf{0 , 8 - 1 , 1 9}$ & $29-31$ & $52-62$ & $0-5$ & $200-$ \\
& & & & 918 \\
$\mathbf{1 , 2 - 1 , 4}$ & $28-30$ & $49-59$ & $0-3$ & $\begin{array}{c}180- \\
\end{array}$ \\
& & & & 634 \\
\hline
\end{tabular}

The tablel shows greater air movement increases the temperature, humidity (Relative Humidity / $\mathrm{RH}$ ), $\mathrm{CO}$, and $\mathrm{CO}_{2}$ tend to decrease. It shows the influence of air circulation devices to improve IAQ. The effect of air velocity on temperature is that any increase in air velocity of $0.2 \mathrm{~m} / \mathrm{s}$ will reduce the temperature of $1{ }^{\circ} \mathrm{C}$. Air humidity decreases by about $1 \%$ at an increase in airspeed of $0.1 \mathrm{~m} / \mathrm{s}$. CO levels decreased by $14 \mathrm{ppm}$ per increase of $1 \mathrm{~m} / \mathrm{s}$ and $\mathrm{CO}_{2}$ levels decreased by $280 \mathrm{ppm}$.

\section{Overall Comfort}

Figure 2 shows that the residential units are in slightly uncomfortable; the situation is too humid according to the psychrometric chart (ASHRAE, 2016). However, the comfort level increased by setting the air circulation speed by $1 \mathrm{~m} / \mathrm{s}$. This result indicates that the importance of air circulation devices in residential units as a result of comfort values and removing pollutants.

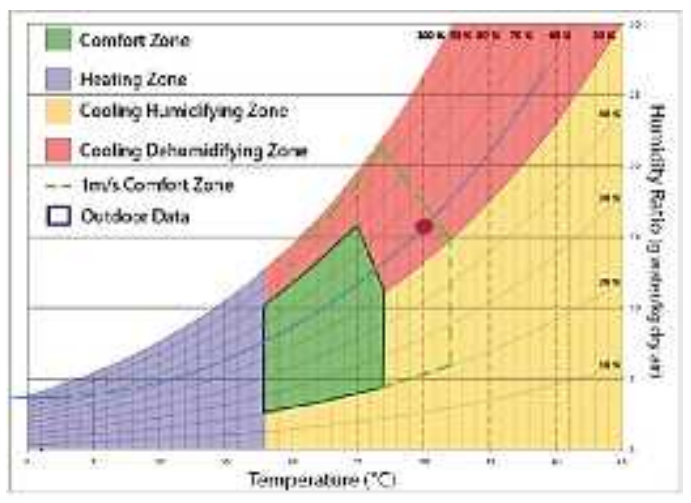

Figure 2. The Result of Psychrometric Chart

The results of the questionnaire on the comfort showed that of 58 residents, $72.4 \%$ felt comfortable, and $27.6 \%$ felt uncomfortable from all aspects of measurement. It means that the residents can tolerate the IAQ in this apartment.

\section{CONCLUSION}

The air circulation system at this apartment showed several factors that influence the value of the air circulation system besides air movement: the size of the room and the adequacy of ventilation in the place. In terms of residents' comfort, the IAQ of this apartment meets SNI 03 6572-2001 criteria, so is categorized as a comfortable condition. Although the air temperature does not reach the standard rules, residents say 
they can adapt by the cloth and low activities.

This study has a limitation on the number of samples because not all residents' unit given permission for entering. For future research, it would be better also to get on the filtering system of $\mathrm{AC}$ and discuss the influencing material unit.

\section{ACKNOWLEDGEMENT}

This work supported by developer and management of Green Pramuka City Apartment.

\section{REFERENCES}

Alfata, M. N. F., Hirata, N., Kubota, T., Nugroho, A. M., Uno, T., Antaryama, I. G. N., \& Ekasiwi, S. N. (2015). Thermal Comfort in Naturally Ventilated Apartments in Surabaya, Indonesia. Procedia Engineering, 121, 459-467. https://doi.org/10.1016/j.proeng.20 15.08.1093

ASHRAE. (2016). ASHRAE Psychrometic Chart No.1. https://www.ashrae.org/File\%20Li brary/Technical\%20Resources/Bo okstore/UP3/SI-1.pdf

Gautami, W., \& Syahruddin, E. (2017). The relationship of Flats in Environmental Conditions with Chronic Respiratory Disease Prevalence in Jakarta. EJournal Kedokteran Indonesia, 1(3). https://doi.org/10.23886/ejki.1.300 4.

Goverment of Republik Indonesia. (2011). Regulation RI No. 1 2011: Perumahan dan Kawasan Permukiman.

Harb, P., Sivachandiran, L., Gaudion, V., Thevenet, F., \& Locoge, N. (2016). The $40 \mathrm{~m} 3$ Innovative experimental Room for INdoor Air studies (IRINA): Development and validations. Chemical Engineering Journal, 306, 568-578. https://doi.org/10.1016/j.cej.2016.0 7.102

Indonesian Standardization Institute. (2001). SNI-The Procedure for Designing Ventilation and Air Conditioning Systems in Buildings (03-6572-2001). 1-55.

Ministry of Health of the Republic of Indonesia. (2011). Regulation of the Minister of Health Number 1077 on Healthy Home Air Guidelines.

Nicklas, S. et al. (2016). ASHRAE Handbook HVAC Systams and Equipment. USA. (28).

Tham, K. W. (2016). Indoor air quality and its effects on humans-A review of challenges and developments in the last 30 years. Energy and Buildings, 130, 637650.

https://doi.org/10.1016/j.enbuild.2 016.08.071

Wells, E. M., Berges, M., Metcalf, M., Kinsella, A., Foreman, K., Dearborn, D. G., \& Greenberg, S. (2015). Indoor air quality and occupant comfort in homes with deep versus conventional energy efficiency renovations. Building and Environment, 93(P2), 331-338. https://doi.org/10.1016/j.buildenv. 2015.06.021

Wolkoff, P. (2018). Indoor air humidity, air quality, and health - An overview. International Journal of Hygiene and Environmental Health, 221(3), 376-390. https://doi.org/10.1016/j.ijheh.201 8.01.015

Xue, P., Mak, C. M., \& Ai, Z. T. (2016). A structured approach to overall environmental satisfaction in high- 
Applied Research on Civil Engineering and Environment (ARCEE) VOL. 01 No. 01, August 2019

rise residential buildings. Energy

and Buildings, 116, 181-189.

https://doi.org/10.1016/j.enbuild.2

016.01 .006 